\title{
Physiological response to thermal stress in hair-sheep ewes during subtropical summer
}

\author{
Indicadores fisiológicos de respuesta al estrés térmico en ovejas de pelo durante el verano \\ subtropical
}

\author{
Javier Alejandro Gómez-Guzmán', José Fernando Vázquez-Armijo², Javier Hernández-Meléndez³, Ana Laura Lara-Rivera ${ }^{4}$ \\ and Gaspar Manuel Parra-Bracamonte ${ }^{1 *}$ \\ ${ }^{1}$ Centro de Biotecnología Genómica, Instituto Politécnico Nacional. México. ${ }^{2}$ Centro Universitario UAEM Temascaltepec, Universidad

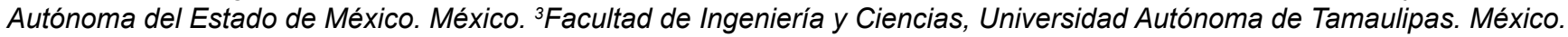 \\ ${ }^{4}$ Facultad de Ciencias Biológicas, Universidad Autónoma de Nuevo León. México. *E-mail: gparra@ipn.mx.
}

\begin{abstract}
With the aim to assess the effect of short-term thermal stress on physiological traits of ewes an experiment was designed. Fourteen hair sheep ewes were selected during early reproductive management and randomly segregated in two groups. Control group (CG) with indoor conditions, and an experimental group (EG) under continuous outdoor conditions without shadow accessing during 14 days (d). Respiratory frequency (RF), rectal temperature (RT) and infrared image temperatures were estimated. Traits were measured for $8 d$ twice a d (9:00 am and 15:00 pm). Environmental temperature and humidity were monitored, and temperature and humidity index was estimated. All physiological and environmental traits showed significantly variation by group and time of measurement $(P<0.001)$. RT and RF were significantly higher for $E G$ and during pm measurements. Environmental conditions indicated thermal stress conditions for outdoor EG during the afternoon was related ultimately with respiratory mechanism as the main indicator of continuous thermal stress. Head infrared image temperature was a good predictor of body temperature.
\end{abstract}

Key words: Heat stress; infrared thermography; respiratory frequency; rectal temperature

\section{RESUMEN}

Con el objetivo de evaluar el efecto a corto plazo del estrés térmico continuo sobre las variables fisiológicas en ovejas, se diseñó un experimento. Catorce ovejas de pelo fueron seleccionadas durante el manejo reproductivo temprano y aleatoriamente segregadas en dos grupos. El grupo Control (CG) con condiciones de sombra y el grupo experimental (EG) en condiciones de exterior sin acceso a sombra durante 14 días (d). La frecuencia respiratoria (FR), temperatura rectal (TR) y temperaturas infrarrojas fueron estimadas. Las variables fueron medidas durante $8 \mathrm{~d}$ dos veces por d (9:00 am and 15:00 pm). La temperatura y humedad ambiental fue monitoreada y el indice de temperatura y humedad fue estimada. Todas las variables mostraron variación significativa por grupo y tiempo de medición $(P<0,001)$. TR y RF fueron significativamente mayores en EG y durante las mediciones en la tarde. Las condiciones ambientales sugieren que el estrés térmico en condiciones exteriores durante la tarde se relaciona más claramente con mecanismo de respiración como principal indicador del estrés térmico a corto plazo. La temperatura infrarroja de la cabeza fue un mejor predictor de temperatura corporal.

Palabras clave: Estrés térmico; frecuencia respiratoria; temperatura rectal; termografía infrarroja 


\section{INTRODUCTION}

Under the global warming scenario, different environments suppose a threat for domestic livestock. Among all the stress conditions, high temperatures are considered the most severe for animal production [4]. Additionally, humidity, radiation, precipitation and wind intensity affect livestock production. Specific weather conditions in particular regions, specifically the air temperature and humidity have direct influence on animal production [1, 23]. The exposure to high temperatures produces significant and drastic changes on biological functions of sheep (Ovis aries), including efficiency in feed use, water metabolism and mineral equilibrium alterations and important consequences in endocrine, metabolite and blood physiology [15].

Animals have a variety of physiological mechanisms for thermolysis, when these mechanisms are not enough to relieve the effect of heat load, body temperature (BT) can rise to the point where animal welfare is compromised [1]. BT is a good measure of heat tolerance in animals, since it is the result of all processes of heat gain and loss in the body. Changes in heart rate (HR), respiratory frequency (RF) and rectal temperature (RT) are the key parameters that indicate the mechanism of physiological adaptation in small ruminants [24]. In environments with heat stress (HS), RF is the first thermoregulation mechanism used by ruminants to help them maintain $\mathrm{BT}$; the panting is a physiological medium recognized as a response to increased environment heat through a substantial increasing in RF [17].

Some studies has assessed the physiological effect of temperature stress on sheep supporting the negative effect on hypothalamus-pituitary-gonads axis [2,21]. Some of these effects are related to the increasing in glucocorticoid level as a stress response stimulating hypothalamus for somatostatin secretion inhibiting growth hormone [11]; additionally, most productive losses in sheep come from a variety of reproductive problems associated thermic stress. In females it directly affects the presence and duration of estrus, displaying low growth of the dominant follicle and reduced concentrations of gonadotropin-releasing and luteinizing hormones, reflected in a lower estrogen synthesis [9].

The corporal temperature observed by different methods such as rectal and thermographic infrared images and RF has been used as indicators of short-term thermic stress in different reproductive and growth stages in sheep [28], but not in early stage of pregnancy. In Pelibuey ewes, the available research indicate that this breed show more effective BT regulation under artificial conditions of environmental hyperthermia [20], less effects on progesterone levels [16] and their embryo percentage apparently is less influenced by artificial hyperthermia [27]. However all these evidences have been assessed under artificial conditions in climate chamber-induced short term hyperthermia but not under natural environment conditions.

The aim of the present study was to estimate the physiological response during early reproductive management of ewes subjected to continuous TS during late summer under exterior management conditions in subtropical late summer, under the hypothesis that, physiological traits of Pelibuey ewes were affected by continuous TS during the studied period.

\section{MATERIALS AND METHODS}

The experiment was conducted during late summer at experimental farm of Facultad de Ingeniería y Ciencias-Universidad Autónoma de Tamaulipas, located in northeast Mexico (2356' N, 9906' W), at 190 meters above sea level. The climate was considered sub-tropical, which is semi-arid and sub-humid, with summer rains and sporadic winter rains. The average annual temperature is $23^{\circ} \mathrm{C}$ with a total annual rainfall of 800 millimeters $(\mathrm{mm})$.

Fourteen hair sheep ewes (2-3 years old and 3-4 body condition score) were treated with an intravaginal sponge impregnated with 20 milligrams $(\mathrm{mg})$ of chronolone (Chronogest $\AA$ CR, Intervet $\AA$ Productions SA, Igoville, France) [22] for 14 days (d). Twenty four hours $(\mathrm{h})$ before sponge withdrawal, 400 international units (IU) of equine chorionic gonadotropin (eCG) (Folligon $®$, Intervet $\circledast$, Boxmeer, Holland) were applied. Ewes in estrus were mated by natural mating around $24 \mathrm{~h}$ after the onset of estrus. After copula, ewes were divided into two groups $(n=7)$. A control group $(C G)$ was managed in a confined system and were kept in roofed pens. A second experimental group (EG) was maintained in a confined system and were kept in unroofed pen from 7:00 am to 7:00 pm, under continuous TS stimulus. Both groups had free access to water and the same isocaloric and iso-protein diet.

The experiment was conducted during eight $d$ of September, measuring twice a d (9:00 am and 15:00 pm) physiological traits of RT and RF; also, BT by infrared images (II), considering the nose, eye, head, back, belly and hip. RT was estimated using a digital thermometer (Neutek MT-201C, Citisalud S.A. de C.V., Mexico). RF, was estimated visually. The II were collected using a Flir 2 camera (Willsonville, Oregon, USA) and processed with Flir Tools software. Complementarily, environmental temperature and humidity were monitored by a hygrothermometer Thermotracker Higro (Culiacan, Sinaloa, México). Configuration of sensors and processing of data will be completed using Thermotracker Pro 3.0 software. Temperature and humidity index (ITH) was computed using the formula described by Mader [14] using the formula \{ITH $=[0.8 \times$ ambient temperature $]+[(\%$ relative humidity $\div 100) \times$ (ambient temperature -14.4$)]+46.4\}$.

All statistical analysis were performed in SAS software ver. 9.0 (Statistical Analysis System, Cary, NC, USA). A mixed model for repeated measures was fitted using the MIXED procedure as:

$$
Y_{i j k}=G_{i}+T_{i}+\beta_{1} I T H_{k}+\varepsilon_{i j k}
$$

Where: Y: physiological and environmental response variables, $G=$ fixed effect of $i$-the group (CG and EG), $T=$ fixed effect of $j$-th time of measurement (am and pm), and the ITH as linear covariate (only for physiological traits). The repeated effect of sheep-day measured adjusted by a Compound Symmetry covariance structure was considered given its best AIC and BIC statistics. Least square means were estimated and compared by a t test with a Tukey adjustment. Pearson correlation coefficients were computed for all variables using the CORR procedure.

\section{RESULTS AND DISCUSSION}

Least square means by group and time of measurement comparison are showed in TABLE I. Both factors were important for all physiological traits evaluated $(P<0.01)$. All temperature estimates (rectal and infrared) were significantly different among 
TABLE I

Effect of the group and the measurement time on physiological traits in hair sheep ewes

\begin{tabular}{ccccc}
\hline \multirow{2}{*}{ Traits } & \multicolumn{2}{c}{ Group } & \multicolumn{2}{c}{ Time } \\
\cline { 2 - 5 } & CG & EG & am & pm \\
\hline RT & $39.34 \pm 0.09 \mathrm{a}$ & $39.65 \pm 0.08 \mathrm{~b}$ & $39.19 \pm 0.12 \mathrm{a}$ & $39.81 \pm 0.10 \mathrm{~b}$ \\
RF & $79.64 \pm 2.65 \mathrm{a}$ & $108.26 \pm 2.22 \mathrm{~b}$ & $67.59 \pm 4.77 \mathrm{a}$ & $120.32 \pm 379 \mathrm{~b}$ \\
Eye & $36.90 \pm 0.32 \mathrm{a}$ & $38.70 \pm 0.26 \mathrm{~b}$ & $36.20 \pm 0.53 \mathrm{a}$ & $39.40 \pm 0.42 \mathrm{~b}$ \\
Nose & $35.77 \pm 0.27 \mathrm{a}$ & $37.36 \pm 0.22 \mathrm{~b}$ & $34.78 \pm 0.48 \mathrm{a}$ & $38.34 \pm 0.37 \mathrm{~b}$ \\
Head & $36.14 \pm 0.43 \mathrm{a}$ & $38.82 \pm 0.37 \mathrm{~b}$ & $35.50 \pm 0.63 \mathrm{a}$ & $39.46 \pm 0.51 \mathrm{~b}$ \\
Belly & $36.25 \pm 0.27 \mathrm{a}$ & $38.47 \pm 0.22 \mathrm{~b}$ & $35.83 \pm 0.49 \mathrm{a}$ & $38.89 \pm 0.38 \mathrm{~b}$ \\
Back & $36.74 \pm 0.63 \mathrm{a}$ & $41.06 \pm 0.53 \mathrm{~b}$ & $36.70 \pm 1.06 \mathrm{a}$ & $41.11 \pm 0.85 \mathrm{~b}$ \\
Hip & $35.89 \pm 0.69 \mathrm{a}$ & $41.14 \pm 0.59 \mathrm{~b}$ & $35.99 \pm 1.11 \mathrm{a}$ & $41.04 \pm 0.90 \mathrm{~b}$ \\
\hline
\end{tabular}

RT: Rectal temperature, ${ }^{\circ} \mathrm{C}, \mathrm{RF}$ : Respiratory frequency, times by minute. CG: Control group.

EG: Experimental group

groups $(P<0.001)$. Temperature indicators showed in general that EG and pm measured ewes had the higher LSmeans. RT showed averaged increasing values of $0.3^{\circ} \mathrm{C}$ for EG compared to $\mathrm{CG}$ and $0.6^{\circ} \mathrm{C}$ during $\mathrm{pm}$. Infrared temperature recording, showed the same pattern or differences, between experimental groups and time of measurement; however, nose had sustained lower temperatures than other corporal sites, with the highest temperatures recorded in ewe back and hip (TABLE I). The most important observed change was in RF; showing a significantly increasing in EG ewes maintained in outdoor conditions, speeding their respirations in almost $30 \%$, and even more during pm measurements (44\%).

Differences in environmental recorded traits prevalent during the experiment in both, experimental groups and time of measurement are presented in TABLE II. Prevalent conditions showed that temperatures during morning measurement in CG were slightly higher than those observed in $E G(P<0.001)$, with higher percentage of humidity for animals maintained under outdoor conditions. However, temperature conditions were consistently higher with almost 10 degrees of difference for outdoor conditions with lower humidity, producing significantly higher ITH estimates (TABLE II).
Correlations among measured indicators are presented in TABLE III. RT showed significant but moderate and low correlations with infrared temperature indicators in CG and significant but low correlations in EG. Interestingly, RF showed moderate to high correlations with infrared temperatures in $C G$, and a significant correlation $(P<0.001)$ of 0.70 with ITH. Conversely, moderate correlations were observer in EG among RF and all infrared temperatures, except with ITH showing a slightly high correlation with ITH $(P<0.001)$. In both, CG and EG, all infrared temperatures were highly correlated $(r>0.7)$. groups. Head infrared temperature showed to be a reliable indicator given its high correlation with all other infrared temperature indicators $(r>0.82)$.

Comfort zone of livestock it is defined as that area with a temperature range, within which the animal can stay without the need to activate its thermal self-regulation mechanisms [3]. The neutral environmental temperature (ET) for sheep was 13 to $31^{\circ} \mathrm{C}$. Therefore, in this study the ET during the morning was not sufficient for the sheep to be under thermal stress; however, in the EG during most of the afternoon an upper difference of $9,2{ }^{\circ} \mathrm{C}$ was observed over the CG with shade availability. Those conditions kept EG ewes in TS during the experiment.

TABLE II

Differences in meteorological parameters between morning and afternoon in both groups sensors during the study

\begin{tabular}{cccc}
\hline Time & Trait & CG & EG \\
\hline \multirow{3}{*}{ am } & Temperature ${ }^{\circ} \mathrm{C}$ & $24.60 \pm 0.27 \mathrm{a}$ & $22.99 \pm 0.25 \mathrm{~b}$ \\
& Humidity $\%$ & $87.64 \pm 0.97 \mathrm{a}$ & $95.06 \pm 0.90 \mathrm{~b}$ \\
& ITH & $75.11 \pm 0.26 \mathrm{a}$ & $73.06 \pm 0.24 \mathrm{~b}$ \\
\cline { 2 - 4 } $\mathrm{pm}$ & Temperature ${ }^{\circ} \mathrm{C}$ & $28.13 \pm 0.18 \mathrm{a}$ & $37.32 \pm 0.16 \mathrm{~b}$ \\
& Humidity $\%$ & $77.72 \pm 0.57 \mathrm{a}$ & $49.24 \pm 0.53 \mathrm{~b}$ \\
& ITH & $79.39 \pm 0.18 \mathrm{a}$ & $87.33 \pm 0.17 \mathrm{~b}$ \\
\hline
\end{tabular}

CG: Control group. EG: Experimental group 
TABLE III

Pearson correlation coefficient among studied physiological traits and ith environmental variable in two assessed groups

\begin{tabular}{|c|c|c|c|c|c|c|c|c|c|}
\hline & RT & $\mathbf{R F}$ & Nose & Eye & Head & Back & Hips & Belly & ITH \\
\hline RT & & $0.51 * * *$ & $0.59 * * *$ & $0.57 * \star \star$ & $0.61 * * *$ & $0.53 * * *$ & $0.53 * * *$ & $0.40 * *$ & $0.29 *$ \\
\hline RF & $0.42 * *$ & & $0.73 * * *$ & $0.73 * * *$ & $0.81 * * *$ & $0.77 * \star *$ & $0.79 * * *$ & $0.79 * * *$ & $0.70 * * *$ \\
\hline Nose & $0.27 *$ & $0.55 * \star \star$ & & $0.85 * * *$ & $0.94 * \star \star$ & $0.84 * * *$ & $0.85 * * *$ & $0.80 * \star \star$ & $0.54^{* * *}$ \\
\hline Eye & 0.36 * & $0.52 * * *$ & $0.79 * * *$ & & $0.89 * * *$ & $0.76 * * *$ & $0.80 * * *$ & $0.73 * * *$ & $0.48 * * *$ \\
\hline Head & 0.36 * & $0.54 * * *$ & $0.82^{* \star *}$ & $0.92 * * *$ & & $0.91 * * *$ & $0.92 * * *$ & $0.88 * * *$ & $0.54^{* \star *}$ \\
\hline Back & $0.41 * *$ & $0.49 * * *$ & $0.65^{* * *}$ & $0.74 * \star \star$ & $0.87 * \star \star$ & & $0.95 * \star \star$ & $0.87 * \star \star$ & $0.46 * *$ \\
\hline Hips & $0.39 *$ & $0.46 * *$ & $0.70 * \star *$ & $0.80 * * *$ & $0.88 * * *$ & $0.89 * \star \star$ & & $0.89 * * *$ & $0.51 * * *$ \\
\hline Belly & 0.36 * & $0.60 * \star \star$ & $0.79 * * *$ & $0.79 * * *$ & $0.84 * * *$ & $0.79 * * *$ & $0.82 * * *$ & & $0.56 * * *$ \\
\hline ITH & 0.17 & $0.72 * * *$ & $0.51 * * *$ & $0.45^{* *}$ & $0.48 * * *$ & $0.43 * *$ & $0.40 *$ & $0.48 * * *$ & \\
\hline
\end{tabular}

Control group: Above diagonal, Experimental group: Below diagonal. RT: Rectal temperature, RF: Respiratory frequency,

ITH, Temperature and humidity index. ${ }^{*} \mathrm{P}<0.05$. $* * \mathrm{P}<0.010$. $* * * \mathrm{P}<0.001$

Some indices have been developed to assess TS. The most common empirical model of heat load is the ITH, which is a combination of temperature and humidity effects in a single value associated with the heat load level and has been used to assess stress [23]. It is established that an ITH of 74 or less is considered normal, 75 to 78 corresponds to an alert stage, 79 to 83 to a danger stage and an ITH equal to or greater than 84 is an emergency [14]. Under these parameters, outdoor EG ewes were borderline a normal and under an ITH above normal and the shadow group was close to being in alert stage. It is considered that due to the decrease in humidity in the CG the temperature is greater and that is enough for the ITH to increase in this group. It is known that according to environmental principles, these variables are inversely proportional [26]. However, the environmental conditions (EC) during afternoon resulted in an ITH which might be dangerous for ewes.

An increase in RT is considered a good indicator of TS in animals. Significant increases in RT associated to ITH during the summer indicate that the animals were in conditions of thermal stress [19]. The EC that were presented in this study allowed to suggest that the increase in RT within both groups was directly related to the increase in ET and ITH. In addition, under the condition of the present study, the significant increase in RT was observed in the EG over the CG; this increase is due to the lack of the body's ability to maintain its thermal equilibrium [6]. Macías et al. [12] reported that in non-lactating ewes the differences in RT increase over the course of the $\mathrm{d}$, being smaller in the morning and greater in the afternoon during the summer season. Similarly, in the study by Silva et al. [26], significant effects of higher RT values were observed in the hottest $h$ of the $d$ which is consistent with the present values observed in both groups during the afternoon.

In the other hand, regarding RF, the criteria for co-monitoring RF as an indicator of stress range from $<61-80$ breaths/minute ( $\mathrm{min}$ ) for medium-high stress and 81-120 breaths/min for high stress [25]. Under this criterion, in the present study the CG presented medium high stress levels and the EG a high stress; the same result can be observed by the time of measurement, since in the morning ewes were in medium high stress and in the afternoon at a high stress level. It is known that sheep that are exposed to high ambient temperatures increase their efforts to dissipate body heat, resulting in an increase in RF [7]. In the present study it was observed that the increase in the ET and ITH during morning and afternoon caused the ewes to present significant increase in the RF, which shows the importance of RF as a mechanism of heat loss in small ruminants. Macias et al. [12] reported that in non-lactating females differences in RF increased during the warmer $h$ during the $d$ due to the activation of mechanisms for heat loss.

For the estimation of animal heat tolerance, RT and RF are the best physiological variables. However, the assessment of adaptability can be complemented with variables such as heart rate and surface temperature [5]. It has also been observed that thermographic evaluation surveys in sheep can adequately assess temperature gradients and identify breeds that have better heat tolerance [10]. Given to a high correlation between environmental indices and sheep surface temperature, the importance of establishing indicative values of thermal discomfort to adopt measures to mitigate thermal stress and not compromise the productive performance has been stated [23]. In the present assessment, the temperature on the hair surface shows significant differences within both groups and time of measurement; this agrees well to the results by Macias et al. [13] reporting lower BT during the mornings and higher at noon. This is because the variation in temperature in animals is influenced by the oscillation of the ambient temperature during the $d$ [18]. In this study, higher temperatures were obtained on the surface of the animal in the EG, which was directly exposed to solar irradiation unlike the group that had access to the shade in the hottest $h$ of the $d$. Solar radiation together with a high ambient temperature is considered to be an important factor for the increase in the temperature of the animal surface. This is due to vasodilation caused by blood capillaries, which increase blood flow to the surface of the animal as a way of 
heat dissipation [8]. In addition, it was observed that within the CG the surface temperature was lower than the RT, which is consistent with that reported by Piccione et al. [26]. Most importantly, the present results showed that within the $E G$, the head temperature showed a moderate correlation RF and ITH $(r \approx 0,50)$, maintaining a high correlation with the other infrared temperature indicators, which can serve as non-invasive means to detect the presence of TS within the flock.

Although it was not possible to assess the punctual effect of continuous TS on reproductive performance of the studied ewes, the results suggest through the physiological traits that some possible effects would be expected. Previous studies in Pelibuey breed have assessed the effect of chamber-induced short term hyperthermia on some reproductive traits. These available research indicate that this breed show more effective BT regulation under artificial conditions of environmental hyperthermia [20], has less effects on progesterone levels during gestational period [16] and that its embryo development percentage apparently is less influenced by artificial hyperthermia [27]. However since these evidences have been assessed under artificial conditions did not allow to fully understand the magnitude of real environmental hyperthermia on ewes performance.

\section{CONCLUSIONS}

Results showed that continuous environmental TS has important effects on physiological traits of Pelibuey ewes during late summer. The main effects of this continuous short-term TS are more observed in RF and BT. Increasing the RF was the best mechanism for heat removal for the ewes during the present study. It also establishes the use of novel methods such as thermal infrared imaging as non-invasive effective was of detection of TS. Finally, the importance of roofed facilities to avoid heat loading in animals was considered, since it was observed that the experimental group presented TS conditions that could possibly damage its production and reproduction.

\section{ACKNOWLEDGEMENTS}

Authors want to thank the Instituto Politécnico Nacional (SIP20195038) and Universidad Autónoma del Estado de México (4766/2019CIB) for the financial support to this study. Fisrt author acknowledges the scholarship granted by the Consejo Nacional de Ciencia y Tecnología-CONACYT, Mexico.

\section{BIBLIOGRAPHIC REFERENCES}

[1] BERIHULAY, H.; ABIED, A.; HE, X.; JIANG, L.; MA, Y. Adaptation Mechanisms of Small Ruminants to Environmental Heat Stress. Anim. 9:75. 2019.

[2] BERNABUCCI, U; LACETERA, N.; BAUMGARD, L.H.; RHOADS, R.P.; RONCHI, B.; NARDONE, A. Metabolic and hormonal acclimation to heat stress in domesticated ruminants. Anim. 4:1167-1183. 2010.

[3] CEDEÑO, A.J.R. Efecto del estrés calórico en el bienestar animal, una revisión en tiempo de cambio climático. Rev. Espamcien. 2(1):15-25. 2011.

[4] DANGI, S.S.; GUPTA, M.; DANGI, S.K.; CHOUHAN, V.S.; MAURYA, V.P.; KUMAR, P.; SINGH, G.; SARKAR, M.
Expression of HSPs: an adaptive mechanism during long-term heat stress in goats (Capra hircus). Int. J. Biomet. 59:10951106. 2015.

[5] DANTAS, N.L.B.; DE SOUZA, B.B.; DA SILVA, M.R.; DE ASSIS-SILVA, G.; DA SILVA-PIRES, J.P.; BATISTA, L.F.; FREITAS, M.; FURTADO, D.A. Effect of the environment and diet on the physiological variables of sheep in the Brazilian semi-arid region. Semin. Ciên. Agrár. 40:971-980. 2019.

[6] DE, K.; KUMAR, D.; BALAGANUR, K.; SAXENA, V.K.; THIRUMURUGAN, P.; NAQVI, S.M.K. Effect of thermal exposure on physiological adaptability and seminal attributes of rams under semi-arid environment. J. Therm. Biol. 65:113118. 2017.

[7] DE, K.; KUMAR, D.; SAXENA, V.K.; NAQVI, S.M.K. Study of circadian rhythmicity of physiological response and skin temperature of sheep during summer and winter in semi-arid tropical environment. Physiol. Behavior. 169:16-21. 2017.

[8] DE, K.; SAXENA, V.K.; KUMAR, D.; MOHAPATRA, A.; BALAGNUR, K.; NAQVI, S.M.K. Oscillatory thermo-regulatory behavior of fecundity-gene-introgressed sheep in the hot semi-arid region. J. Vet. Behavior. 33: 75-80. 2019.

[9] GASTELUM-DELGADO, M.A.; AVENDAÑO-REYES, L.; ÁLVAREZ-VALENZUELA, F.D.; CORREA-CALDERÓN, A.; MEZA-HERRERA, C.A.; MELLADO, M.; MACÍAS-CRUZ, $U$. Conducta estral circanual en ovejas Pelibuey bajo condiciones áridas del noroeste de México. Rev. Mex. Cien. Pec. 6:109-118. 2015.

[10] JÚNIOR, C.C.; LUCCI, C.M.; PERIPOLLI, V.; TANURE, C.B.; RIBEIRO, L.M.C.S.; BARBOSA, T.M.; RAMOS, A.F.; LOUVANDINI, H.; MCMANUS, C. Laser and thermographic infrared temperatures associated with heat tolerance in adult rams. Small Rumin. Res. 132:86-91. 2015.

[11] KUMAR, B.; MANUJA, A.; AICH, P. Stress and its impact on farm animals. Front. BioSci. 4:1759-1767. 2012.

[12] MACÍAS-CRUZ, U.; CORREA-CALDERÓN, A.; MELLADO, M.; MEZA-HERRERA, C.A.; ARÉCHIGA, C.F.; AVENDAÑOREYES, L. Thermoregulatory response to outdoor heat stress of hair sheep females at different physiological state. Int. J. Biometeor. 62(12): 2151-2160. 2018.

[13] MACÍAS-CRUZ, U.; GASTÉLUM, M.A.; AVENDAÑO-REYES, L.; CORREA-CALDERÓN, A.; MELLADO, M.; CHAYCANUL, A.; ARECHIGA, C.F. Variaciones en las respuestas termoregulatorias de ovejas de pelo durante los meses de verano en un clima desértico. Rev. Mex. Cien. Pec. 9:738753. 2018.

[14] MADER, T.L.; DAVIS, M.S.; BROWN-BRANDL, T. Environmental factors influencing heat stress in feedlot cattle. J. Anim. Sci. 84:712-719. 2006.

[15] MARAI, I.F.M.; EL-DARAWANY, A.A.; FADIEL, A.; ABDELHAFEZ, M.A.M. Reproductive performance traits as affected by heat stress and its alleviation in sheep. Trop. Subtrop. Agroecosyst. 8(3):209-234. 2018. 
[16] MENDOZA, M. R.; MONTALDO, H. H.; SÁNCHEZ, J. A. B.; MENDOZA, J. H. C. R.; CERÓN, J. H. Serum progesterone levels in Pelibuey and Suffolk ewes under thermal stress. Vet. Méx. 40: 197-202. 2009.

[17] NEJAD, J.G.; SUNG, K.I. Behavioral and physiological changes during heat stress in Corriedale ewes exposed to water deprivation. J. Anim. Sci. Technol. 59(1): 13. 2017.

[18] PICCIONE, G.; GIANESELLA, M.; MORGANTE, M.; REFINETTI, R. Daily rhythmicity of core and surface temperatures of sheep kept under thermoneutrality or in the cold. Res. Vet. Sci. 95:261-265. 2013.

[19] RATHWA, S.D.; VASAVA, A.A.; PATHAN, M.M.; MADHIRA, S.P.; PATEL, Y.G.; PANDE, A.M. Effect of season on physiological, biochemical, hormonal, and oxidative stress parameters of indigenous sheep. Vet. World 10:650. 2017.

[20 ]ROMERO, R. D.; PARDO, A. M.; MONTALDO, H. H.; RODRÍGUEZ, A. D.; CERÓN, J. H. Differences in body temperature, cell viability, and HSP-70 concentrations between Pelibuey and Suffolk sheep under heat stress. Trop. Anim. Health Prod. 45: 1691-1696. 2013.

[21] ROMO-BARRON, C.B.; DIAZ, D.; PORTILLO-LOERA, J.J.; ROMO-RUBIO, J.A.; JIMENEZ-TREJO, F.; MONTEROPARDO, A. Impact of heat stress on the reproductive performance and physiology of ewes: a systematic review and meta-analyses. Int. J. Biometeor. 63:1-14. 2019.

[22] SCUDAMORE, C.L. Intravaginal sponge insertion technique. Vet. Rec. 123: 554. 1988.
[23] SEIXAS, L.; DE MELO, C.B.; TANURE, C.B.; PERIPOLLI, V.; MCMANUS, C. Heat tolerance in Brazilian hair sheep. Asian-Austral. J. Anim. Sci. 30:593. 2017.

[24] SEJIAN, V.; KUMAR, D.; GAUGHAN, J.B.; NAQVI, S.M. Effect of multiple environmental stressors on the adaptive capability of Malpura rams based on physiological responses in a semiarid tropical environment. J. Vet. Behav. 17:6-13. 2017.

[25] SILANIKOVE, N. Effects of heat stress on the welfare of extensively managed domestic ruminants. Livest. Prod. Sci. 6: 1-18. 2008.

[26] SILVA, A.L.; SANTANA, M.; SOUSA, P.; ALMEIDA-JÚNIOR, T.F.; FARIAS, L.; SOUSA-JÚNIOR, S.C. Avaliação das variáveis fisiológicas de ovinos Santa Inês sob influência do ambiente semiárido piauiense. J. Anim. Behav. Biometeor. 3: 69-72. 2015.

[27] TABAREZ-ROJAS, A.; PORRAS-ALMERAYA, A.; VAQUERAHUERTA, H.; HERNÁNDEZ-IGNACIO, J.; VALENCIA, J.; ROJAS-MAYA, S.; HERNÁNDEZ-CERÓN, J. Desarrollo embrionario en ovejas Pelibuey y Suffolk en condiciones de estrés calórico. AgroCien. 43: 671-680. 2009.

[28] VICENTE-PÉREZ, R.; MACÍAS-CRUZ, U.; AVENDAÑOREYES, L.; CORREA-CALDERÓN, A.; LUNA-PALOMERA, C.; CHAY-CANUL, A.J. Relación de temperatura rectal y frecuencia respiratoria con temperaturas de pelo obtenidas por termografía en ovejas gestantes estresadas por calor. ITEA 115: 219-230. 2019. 